\title{
IR Bagendit Paddy Leaves Extract Improves Liver Cell Morphology and Reduces The Activity of Transaminase Enzymes After Lead Exposure in Rat
}

\author{
Budi Santosa ${ }^{1}$, Henna Ria Sunoko², Andri Sukeksi ${ }^{1}$, Siti Thomas Zulaikhah ${ }^{3, *}$ \\ ${ }^{1}$ Departement of Medical Laboratory Science, Faculty of Nursing and Health Sciences, Universitas Muhammadiyah Semarang, \\ Jl. Kedungmundu Raya No.18, Semarang 50273, Indonesia \\ ${ }^{2}$ Departement of Pharmacy, Faculty of Medicine, Universitas Diponegoro, Jl. Prof. Soedarto, Semarang 50275, Indonesia \\ ${ }^{3}$ Departement of Public Health, Faculty of Medicine, Universitas Islam Sultan Agung, Jl. Kaligawe Raya KM. 4, Semarang 50112, Indonesia \\ *Corresponding author. E-mail: sitithomas@unissula.ac.id
}

Received date: Sep 5, 2019; Revised date: May 26, 2020; Accepted date: May 27, 2020

\section{Abstract}

$\mathrm{B}$ ACKGROUND: Lead $(\mathrm{Pb})$ was known as one of systemic toxic agent. In the body, lead may be deactivated by the metallothioneins. Paddy leaves contain metallothioneins, sugars and pythosterols, and studies have shown the pharmacological activity of rice leaves on the protective effect of lead-induced rats against kidney function. The aim of this study was to evaluate the role of IR Bagendit paddy leaves extract as hepatoprotective agent.

METHODS: Twenty-eight rats were divided into four groups: one control and three treatment groups. Control and treatment groups were exposed to lead of $0.5 \mathrm{~g} / \mathrm{kg}$ body weight $(\mathrm{BW}) /$ day and then the treatment groups were administered with paddy leaves extract of $0.2 ; 0.4$; and $0.8 \mathrm{~g} / \mathrm{kg} \mathrm{BW} /$ day per oral for 8 weeks. On the last day of the $8^{\text {th }}$ week, body weight was measured and the numbers of normal, degenerative and necrotic liver cells were examined with hematoxylin-eosin staining. Serum glutamic

\section{Introduction}

Lead $(\mathrm{Pb})$ has been used in more than 900 industries, including mining, smelting, refining, battery manufacturing and so on.(1) Lead exposures have serious consequences for the health. In the high levels of exposure, lead could induce brain and central nervous system damage, coma, convulsions and even death. Chronic lead poisoning may oxaloacetic transaminase (SGOT) and serum glutamic pyruvic transaminase (SGPT) were measured as liver function parameter. Difference of variables between control and treatment groups were examined by Friedman test.

RESULTS: There was no association in different BW between groups. The normal liver cells are higher in treatment than control group $(p<0.001)$ and necrotic liver cells are lower in treatment than control group $(p \leq 0.001)$. There was no association in degenerative liver cells between groups $(p=0.153)$. The activity of transaminase enzymes are lower in treatment than control group $(p<0.001)$.

CONCLUSION: IR Bagendit Paddy leaves extract reveals hepatoprotective activity by improving liver cells morphology and reducing the activity of transaminase enzymes after lead exposure.

KEYWORDS: paddy leaves extract, liver normal cell, necrotic cell, transaminase enzymes

Indones Biomed J. 2020; 12(3): 227-32 be left with mental retardation and behavioural disorders in children.

Liver is one of the most complex and largest metabolism organs in the body. It involves in each metabolism of the food substances, most drugs and toxicants.(2) Lead is one of liver damage inducing toxicants. The mechanism of liver injury can be separated as biochemical and immune mechanism. The biochemical mechanism involves various chemical agents those 
are metabolized in the liver via phase 1 and phase 2 metabolisms. The metabolite products may alter the intracelluar homeostatis, mitochondria or other organels. The immune mechanism involves cell cooperation and is mediated with complement, cytokines or nitrogen oxide (NOx). Lead may involves directly in normal biochemical process in hepatobiliary system. $(3,4)$

High concentration of lead is toxic to the cells. Lead will act as prooxidant and bind to organic molecules. In the cell, lead ions bind to the cellular proteins and convert the protein structure into the inactive conformation. $(5,6)$ Intraperitoneal administration of $20 \mathrm{mg} / \mathrm{kg}$ body weight (BW) lead acetate in rats resulted histopathologic and biochemical changes in liver, prooxidant and antioxidant balance disorders, oxidative stress, lipid peroxidase.(7)

Paddy leaves water extract contains sucrose, oxalate, $\beta$-sitosterol, stimagsterol and metallothionein. $(8,9)$ Previous studies have shown the pharmacological activity of rice leaves on the protective effect of lead-induced rats against kidney function (10) and blood toxicity (11). Metallothionein is a protein/polypeptide with small molecular mass (4-8 kDa), containing cysteine amino acid (Cys), but having no aromatic amino acid or histidine. The classification of metallothionein is based on the composition of amino acid, number and division of Cys-amino in sequence, and the similarity of phylogenic sequence and relationship.(12) Metallothionein is a protein rich of sulfidryl groups and may bind covalently with lead.(13-16) Previous study showed that paddy leaves, especially Bagendit IR has the highest metallothionein content.(8) In this study, the effects of paddy leaf extract on liver cell morphology and liver function after lead exposure in rats will be evaluated.

\section{Methods}

\section{Determination and Extraction of IR Bagendit Paddy Leaves}

Fresh Paddy leaves were cleaned and washed with destilated water. The leaves were dried at the room temperature, pulverized with mortar and sieved at $0.1 \mathrm{~mm}$ diameter size. One-hundred g pulverized leaves were put in the bottle and destillated water was added up to $1 \mathrm{~kg}$ as total volume. The mixture was boiled and filtered through a filter paper.(14) The extract was kept and used for animal study.

\section{Animal Model}

Healthy white Rattus norvegicus, 180-220 g, aged 15 weeks in condition, were acclimatized for 7 days, housed in cages, and maintained under standard laboratory conditions with dark and light cycles (12/12 hours) according to the ethical standards. Standard feed and drink were given ad libitum. No vitamin was added. Ethical permission for this study was obtained from the Ethics Commission of Medical Faculty of Universitas Sultan Agung Islamic, Semarang (No. 209/ VI/2017/Komisi Bioetik).

\section{Animal Treatment and Sample Collection}

An experimental research with randomized post-test only control-group design was conducted. The sample size was calculated with the formula $\mathrm{BS}=(\mathrm{t}-1)(\mathrm{r}-1) \geq 15$.

Twenty-eight rates in this study were divided into 4 groups, which were 1 control and 3 treatment groups. The control group was given lead acetate $0.5 \mathrm{~g} / \mathrm{kg} \mathrm{BW}$, food and drink. Meanwhile, the treatment groups were given $0.5 \mathrm{~g} / \mathrm{kg}$ lead acetate BW and $0.2 \mathrm{~mL}$ (T1 group), $0.4 \mathrm{~mL}$ (T2 group) and $0.8 \mathrm{~mL}$ (T3 group) IR bagendite paddy leaves extract. Lead exposure and paddy leaves extract administration were administered to both control and treatment groups for 8 weeks. After that all rats were sacrificed. The liver and heart were immediately dissected, weighed, transferred into the tubes with Bouin solution and paraffinized. Blood was drawn from orbital vein. Serum was separated by centrifugation at 5,000 rpm for 10 minutes and kept in frozen storage.

\section{Hematoxyline-Eosin (HE) Staining}

Paraffinized tissues were sectioned and placed on the glass slides. Then the tissue slides were deparaffinized, rehydrated, dipped in hematoxylin, eosin, and washed with water. Then the slides were dehydrated, mounted with cover glass and observed under a 40x-magnified light-microscope. Manual observation was carried out by 2 operators. Histological examinations of the liver were carried out in 5 microscopic fields for each slide. Histopathological changes were observed in the form of congestion, inflammatory cell infiltration, and necrosis.

\section{Scoring and Identification of Liver Cell}

The cell numbers were the number for liver cell that were counted per every 100 cells for each groups. Normal pattern liver lobules were observed with the central vein in the middle and liver cell cords radiating towards the periphery. The areas containing the hepatic artery, portal vein and bile duct were surrounded by connective tissue. Sinusoids were observed between the liver cell cords, and the polygonalshaped hepatocytes mostly contained a single oval-shaped euchromatic nucleus. 
Degenerative liver cell were observed focal parenchymal necrosis together with evidence of regeneration and many hypertrophic, often multinucleated liver cells. The hypertrophic liver cells were often observed to contain peculiar inclusions of irregular size and shape, located predominantly at the periphery of the cytoplasm. Necrotic liver cell were identified using the criteria as increased eosinophilia, cell swelling and lysis, loss of architecture, karyolysis and karyorrhexis.

\section{Measurements of Serum Glutamic Oxaloacetic Transaminase (SGOT) and Serum Glutamic Pyruvic Transaminase (SGPT)}

SGOT and SGPT measurements were conducted based on SGOT kit (Catalog No. 26019983 021, Diasys Diagnostic System GmbH, Holzheim, Germany) and SGPT kit (Catalog No. 27019983 021, Diasys Diagnostic System $\mathrm{GmbH})$ from the manufacturer. The principle of SGPT measurement was based on the changes L-alanine and 2-Oxoglutarate to L-Glutamate and pyruvate. The pyruvate formed reacted with nicotinamide adenine dinucleotide (NADH) to D-lactate and $\mathrm{NAD}^{+}$. The $\mathrm{NAD}^{+}$formation was measured using kinetic method. Meanwhile, the principle of SGOT measurement was based on the changes L-aspartate and 2-oxoglutarate to L-glutamate and oxalacetate. The oxalacetate formed reacted with NADH to D-lactate and $\mathrm{NAD}^{+}$. The $\mathrm{NAD}^{+}$formation is measured using kinetic method as well.

\section{Statistical Analysis}

Data distribution was tested with kolmogorov-smirnov test. Normal data was expressed as mean \pm SD and abnomal data was expressed as median with min-max values. The differences between multiple groups were calculated by Friedman test. The differences between 2 groups were calculated by Mann Whitney test. The statistical calculations were performed using SPSS version 16.0 (IBM Corporation, New York, USA).

\section{Results}

\section{Rats' BW}

The rats' BW measurement was conducted at the baseline and the end of the study. Based on the results of BW measurements before and after treatment, BW difference data of T1 and T3 groups were lower than the control group (Table 1).

\section{Liver Cells Morphology}

In the control group, there were many necrotic and degenerative cells but few normal cells. In contrast with $\mathrm{T} 1, \mathrm{~T} 2$ and $\mathrm{T} 3$ groups, there were more normal cells than degenerative or necrotic cells (Figure 1).

The average and $p$-value of liver normal, degenerative, and tubular necrotic cells were shown in Table 2. Based on Table 2, number of normal cells was higher in the treatment groups than the control group and the highest number was found in T3 group. Number of necrotic cells were lower then in the treatment groups and the lowest number was found in the T3 group.

Friedman test results showed that there was a strong positive relationship $(p<0.001)$ in the number of normal cells and paddy leaves extract dose, suggesting that higher dosage of IR Bagendit paddy leaves extract resulted higher number of liver normal cells. In contrast, the number of necrotic cells are lower depending on the dose of paddy leaves extract $(p<0.001)$. There was no relationship between number of degenerative cells and paddy leaves extract dose.

\section{Liver Functions}

SGOT levels of all treatment groups were lower than the one of control group $(p<0.001)$ but there was no association between the treatment groups (Table 3). There was no significant difference between the treatment groups.

SGPT levels of all treatment groups were lower than control group $(p<0.001)$ but there was no association

Table 1. The difference of body weight before and after treatment.

\begin{tabular}{lcccc}
\hline \multirow{2}{*}{ Group } & \multicolumn{3}{c}{ Body Weight (g) } \\
\cline { 2 - 5 } & Before & After & Difference & $\boldsymbol{p}_{\text {-value* }}$ \\
\hline Control & $180.2(169.9-206.7)$ & $215.8(70.6-256.2)$ & $24.6(-1.6-51.1)$ & \\
T1 & $197.4(154.1-214.4)$ & $208.9(192.1-220.7)$ & $9.0(-5.7-58.9)$ & 0.012 \\
T2 & $161.5(144.2-181.3)$ & $191.2(160.5-240.6)$ & $27.3(-1.0-59.3)$ & \\
T3 & $150.1(135.9-179.4)$ & $173.9(150.3-210.0)$ & $15.6(-16.1-74.1)$ & \\
\hline
\end{tabular}

*The differences between multiple groups were calculated by Friedman test. 

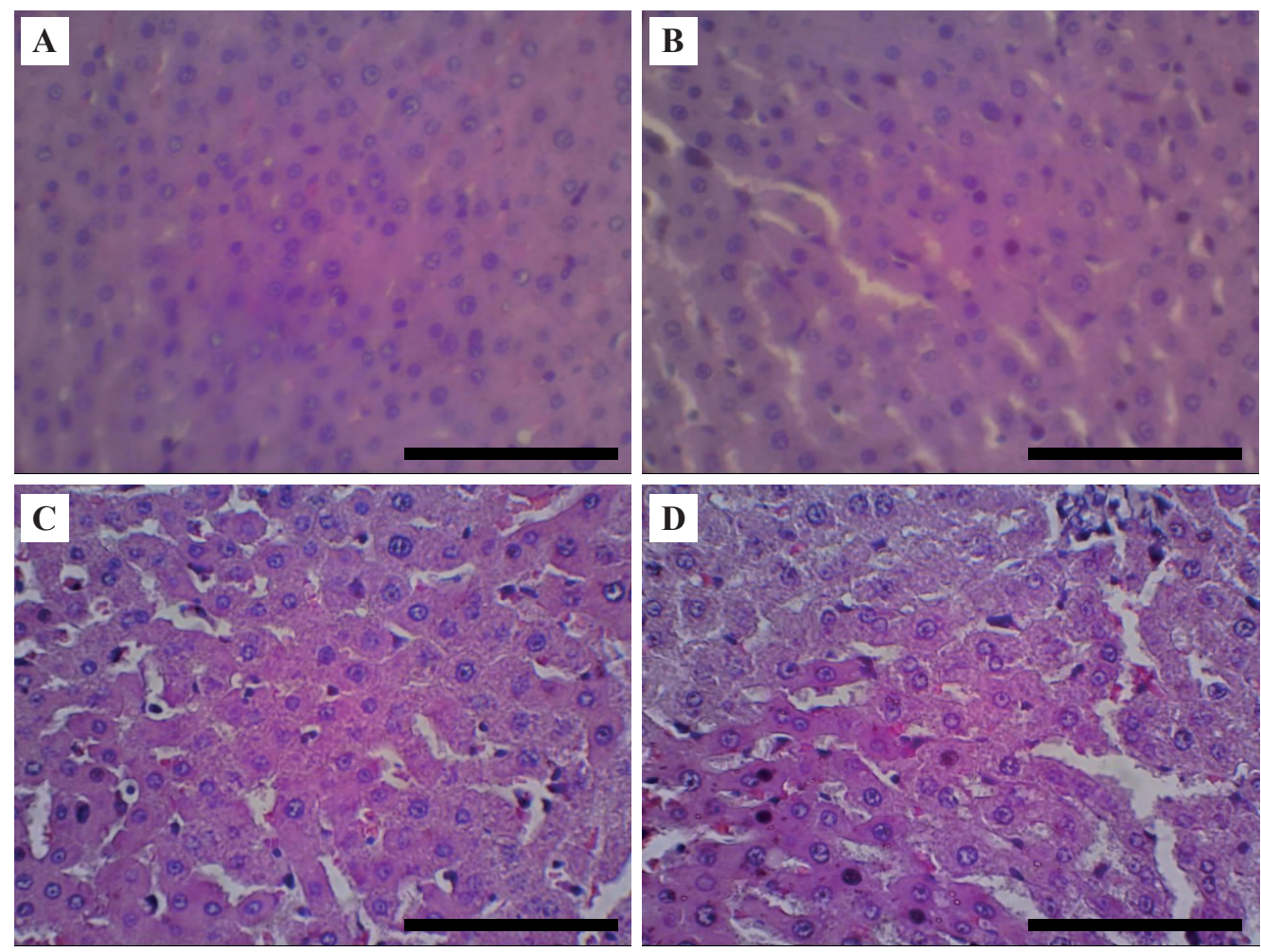

Figure 1. Liver cells morphology between control and treatment groups. A: Control group; B: Treatment T1 group; C: Treatment T2 group; D: Treatment T3 group. Black bar: $100 \mu \mathrm{m}$.

between the treatment groups (Table 4). The average of SGPT levels in treatment groups was around $35 \mu / \mathrm{L}$, while the average of SGPT levels in control group was $40 \mu / \mathrm{L}$.

\section{Discussion}

There was an association of BW difference between control and treatment groups in this study. The treatment groups had lower BW difference than the control group. A previous study reported that lead-exposed rats had BW reduction. $(17,18)$ Several factors, such as lead dose, period of exposure, nutrition, could affect these findings.
Liver is a vital organ that has many functions. Many chemicals could induce liver dysfunction. These chemical agents came from food, occupation or environment.(19) Lead will induce liver damage. As prooxidant, lead affect hepatobiliary system, oxidize unsaturated fatty acids, reduce nitrogen oxide and increase hydroxyl radicals.(20)

The histopathological studies are the evidence of efficacy of drug as hepatoprotective agent. Simultaneous treatment IR Bagendit paddy leaves extract improves the liver cells morphology. Dose of paddy leaves extract was positively associated with the number of normal cells and negatively associated with the number of degenerative cells. Dose of paddy leaves extract was not associated with the

Table 2. Liver cells morphology quantification.

\begin{tabular}{|c|c|c|c|c|c|c|}
\hline \multirow{2}{*}{ Group } & \multicolumn{2}{|c|}{ Normal Cells } & \multicolumn{2}{|c|}{ Degenerative Cells } & \multicolumn{2}{|c|}{ Necrotic Cells } \\
\hline & Average & $p$-value & Average & $p$-value & Average & $p$-value \\
\hline Control & $23.71 \pm 2.69$ & \multirow{4}{*}{$<0.001$} & $21.42 \pm 2.43$ & \multirow{4}{*}{0.153} & $54.85 \pm 3.18$ & \multirow{4}{*}{$<0.001$} \\
\hline $\mathrm{T} 1$ & $37.33 \pm 5.78$ & & $16.00 \pm 4.09$ & & $46.66 \pm 3.50$ & \\
\hline $\mathrm{T} 2$ & $36.57 \pm 4.42$ & & $20.42 \pm 5.85$ & & $43.00 \pm 2.30$ & \\
\hline $\mathrm{T} 3$ & $46.00 \pm 10.27$ & & $18.80 \pm 4.08$ & & $35.20 \pm 9.83$ & \\
\hline
\end{tabular}

*The differences between multiple groups were calculated by Friedman test. 
Table 3. Average of SGOT levels in control and treatment groups.

\begin{tabular}{lcc}
\hline \multirow{2}{*}{ Group } & \multicolumn{2}{c}{ SGOT Level } \\
\cline { 2 - 3 } & Average $(\boldsymbol{\mu} / \mathbf{L})$ & $\boldsymbol{p}$-value \\
\hline Control & $79.57 \pm 24.60$ & \\
T1 & $62.50 \pm 33.15$ & $<0.001$ \\
T2 & $64.00 \pm 26.28$ & \\
T3 & $60.40 \pm 20.79$ & \\
\hline
\end{tabular}

*The differences between multiple groups were calculated by Friedman test.

number of necrotic cells. Phytosterols and metallothioneins are in group of active agent in paddy leaves extract. $(8,9)$ These compounds have antioxidant activity.(21-23) Metallothioneins also have activity as metals chelating agent.(24,25) Metallothioneins can bind lead in digestive tract and in the systemic circulation. $(24,26)$ This condition will prevent the formation of free radicals. Reduction of free radicals will prevent cells damage. In this paddy leaves extract, degenerative cells may return to normal cell.(27)

Liver transaminases can be used to monitor liver damage. SGPT and SGOT are the most commonly used biomarkers of liver damage. SGPT is involved in the transfer of an amino group from alanine and presents in the cytoplasm. SGPT can be found in various tissues, mostly in liver. SGPT is a good biomarker of hepatocellular injury. SGOT is involved in the transfer of an amino group from aspartate. More than $80 \%$ of SGOT is present in the mitochondria and the remaining $20 \%$ of SGOT is present in the cytoplasm. In case of mitochondrial damage, SGOT activity increases more than SGPT.(25) In this study, SGOT and SGPT level are higher in control group than the treatment group $(p<0.001)$. However, increasing the dose of paddy leaves extract did not significantly reduce the activity of the transaminase enzymes.

Table 4. Average of SGPT levels in control and treatment groups.

\begin{tabular}{lcl}
\hline \multirow{2}{*}{ Group } & \multicolumn{2}{c}{ SGPT Level } \\
\cline { 2 - 3 } & Average $(\boldsymbol{\mu} / \mathbf{L})$ & $\boldsymbol{p}$-value \\
\hline Control & $40.28 \pm 9.46$ & \\
T1 & $35 \pm 14.56$ & $<0.001$ \\
T2 & $34.71 \pm 12.4$ & \\
T3 & $34.8 \pm 11.12$ & \\
\hline
\end{tabular}

*The differences between multiple groups were calculated by Friedman test.

\section{Conclusion}

IR Bagendit Paddy leaves extract reveals hepatoprotective activity by improving liver cells morphology and reducing the activity of transaminase enzymes after lead exposure.

\section{Acknowledgements}

This research was granted by Hibah Bersaing 2016, the Ministry of Research, Technology, and Higher Education, Republic of Indonesia (MRTHE) (No. 269/SP2H/LT/ DRPM/II/2016).

\section{References}

1. Mohammadi S, Mehrparvar A, Aghilinejad M. Appendectomy due to lead poisoning: a case-report. J Occup Med Toxicol. 2008; 3: 23. doi: 10.1186/1745-6673-3-23.

2. Guengerich PF. Mechanisms of drug toxicity and relevance to pharmaceutical development. Drug Metab Pharmacokinet. 2011; 26: 3-14.

3. Santosa MH. Uji toksisitas akut dan subakut ekstrak etanol dan ekstrak air kulit batang Artocarpus champeden Spreng. dengan parameter histopatologi hati mencit. Maj Far Airlangga. 2005; 5: 91-5.

4. Rosmaidar, Nazaruddin, Winaruddin, Balqis U, Armansyah T. The effect of lead $(\mathrm{Pb})$ exposure to the histopathology of Nile tilapia (Oreochromis nilloticus) liver. JIMVET. 2017; 1: 742-8.

5. Hernández NMP, Marroquín HLA, Mayagoitia BS, Arenas GG, Hernández MR, Guzmán EMA, et al. Lead-, cadmium-, and arsenic-induced DNA damage in rat germinal cells. DNA Cell Biol. 2009; 28: 241-8.

6. Sharma S, Raghuvanshi BP, Shukla S. Toxic effects of lead exposure in rats: involvement of oxidative stress, genotoxic effect, and the beneficial role of $\mathrm{N}$-acetylcysteine supplemented with selenium. J Environ Pathol Toxicol Oncol. 2014; 33: 19-32.

7. Gajawat S, Sancheti G, Goyal PK. Protection against lead induced hepatic lesion in Swisss Albino mice by ascorbic acid Pharmacologyonline. 2006; 1: 140-9.

8. Santosa B, Sunoko HR. Analysis, identification, and formulation of metallothionein extracts on numerous varieties of Paddy Leaves. Semnas Unimus. 2017; 4: 95-9.

9. Iswanto EH, Praptana RH, Guswara A. Peran senyawa metabolit sekunder tanaman padi terhadap ketahanan wereng cokelat (Nilaparvata lugens). Iptek Tanam Pangan. 2016; 11: 127-32.

10. Santosa B, Sunoko HR, Sukeksi A. Rice leaf extract for kidney damage prevention in plumbum-exposed rats. Int Sem Educ Technol. 2016; 1: 213-7.

11. Santosa B, Sunoko HR, Sukeksi A. Ekstrak air daun padi memperbaiki hematopoesis pada tikus yang terpajan plumbum. Bandung Med J. 2015; 47: 84-90

12. Davis SR, Cousin, JR. Metallothionein expression in animal: a physiological perspective on function. J Nutr. 2000; 130: 1085 8 . 
13. Murray RK. Porphyrin and Bile Pigments. In: Murray RK, Granner DK, Rodwell VW. Harper's Illustrated Biochemistry. 27th ed. New York: McGraw-Hill; 2006. p.279-93.

14. Wong DL, Merrifield-MacRae ME, Stillman MJ. Lead(II) binding in metallothioneins. Met Ions Life Sci. 2017; 17: $9783110434330-$ 009. doi: 10.1515/9783110434330-009.

15. Dai S, Yin Z, Yuan G, Lu H, Jia R, Xu J, et al. Quantification of metallothionein on the liver and kidney of rats by subchronic lead and cadmium in combination. Environ Toxicol Pharmacol. 2013; 36: 1207-16.

16. Gonick HC. Lead-binding proteins: a review. J Toxicol. 2011; 2011: 686050. doi: 10.1155/2011/686050.

17. Nabil MI, Esam AE, Hossam SE, Yasmin EAM. Effect of lead acetate toxicity on experimental male albino rat. Asian Pac J Trop Biomed. 2012; 2012: 41-6.

18. Hariono B. Efek pemberian plumbum (timah hitam) pada tikus putih (Rattus norvegicus). J Sain Vet. 2006; 24: 125-33.

19. Fidiyatun, Setiani O, Suhartono. The association between blood lead level and liver disfunction on exposed lead workers in Tegal District. J Kes Ling Indones. 2013; 12: 149-53.

20. Pagliara P, Carla EC, Caforio S, Chionna A, Massa S, Abbro L, et.al. Kuffer cells promote lead nitrate induced hepatocyte apptosis via oxidative stress. Comp Hepatol. 2003; 2: 1-13.
21. Kozłowska M, Gruczyńska E, Ścibisz I, Rudzińska M. Fatty acids and sterols composition, and antioxidant activity of oils extracted from plant seeds. Food Chem. 2016; 213: 450-6.

22. Huang SS, Deng JS, Chen HJ, Lin YH, Huang GJ. Antioxidant activities of two metallothionein-like proteins from sweet potato (Ipomoea batatas [L.] Lam. 'Tainong 57') storage roots and their synthesized peptides. Bot Stud. 2014; 55: 64. doi: 10.1186/s40529014-0064-4.

23. Kepinska M, Kizek R, Milnerowicz H. Metallothionein and superoxide dismutase - antioxidative protein status in fullerenedoxorubicin delivery to MCF-7 human breast cancer cells. Int J Mol Sci. 2018; 19: 3253. doi:10.3390/ijms19103253.

24. Xiao X, Zhang C, Liu D, Bai W, Zhang Q, Xiang Q, et al. Prevention of gastrointestinal lead poisoning using recombinant Lactococcus lactis expressing human metallothionein-I fusion protein. Sci Report. 2016; 6: 23716. doi: 10.1038/srep23716.

25. Kim YJ. Interpretation of liver function tests. Korean J Gastroenterol. 2008; 51: 219-24.

26. Ruttkay-Nedecky B, Nejdl L, Gumulec J, Zitka O, Masarik M, Eckschlager T, et al. The role of metallothionein in oxidative stress. Int J Mol Sci. 2013; 14: 6044-66.

27. Richard N, Michel MD, Ramzi S, Cotran. Robins Pathologic Basic of Disease. 7th ed. Philadelphia: Saunders; 2004. 